\title{
One Tormenting Night in the Torn and Agonizing Life of a Writer Who Offended God and His Prophet
}

\author{
Zahid Hussain Khan ${ }^{1, *}$ \\ ${ }^{1}$ Department of Anesthesiology Critical Care, Imam Khomeini Hospital Complex, Tehran University of Medical Sciences, Tehran, Iran \\ "Corresponding author: MD, FCCM, Prof., Department of Anesthesiology Critical Care, Imam Khomeini Hospital Complex, Tehran University of Medical Sciences, Tehran, Iran. \\ Email: khanzh51@yahoo.com
}

Received 2020 April 21; Accepted 2020 April 21.

Keywords: The God, Prophet, Religious Belief

"Leave me alone! Let me have a sound sleep tonight. I feel scared. I do repent for my evil work. I am being receptive and no longer arrogant. Help me. Save my skin and my soul. I am being punished for my perversion." Yelled the writer at the top of his lungs in his nightmarish dream.

One of his guards who were on duty for the writer's protection came in and said, "Is anything wrong?"

The writer got up from his bed and said, "No, things are fine. I just had a bad dream."

Another guard who was smoking a cigarette took a deep puff and said, "Such dreams and hallucinations have become part and parcel of your life."

The writer adjusted his spectacles and replied sorrowfully, "You are right. The witches in the Shakespearian tragedy, Macbeth, which I used to see in the theatre halls in London, harass me at nights. I see their horrifying shadows clad in black approaching slowly towards me, and it appears as if they are going to throttle my neck with their sharp claws and clutches." The first guard placed his cap on the table and leaned in an armchair. He had been keeping watch since midnight and looked tired. He took a deep sigh and said, "I feel sorry for authors who delve into unchartered territories and earn themselves lifelong resentment, nostalgia, psychological trauma, and persistent fear of death."

The two guards are symbols of the two angels, namely Keram-al-Katebin, believed by Muslims to record all the good and bad deeds/acts of all human beings. God Almighty says in the Holy Quran about his prophet Mohammad, "We exalted and elevated you to be virtuously remembered." The prophet's name is followed by Durud. These are God's orders.

The second guard said authoritatively, "Your book was an orchestrated attempt by you and your 'godfathers' in the west to defame the holy prophet, Mohammad."

The writer replied abruptly, "I did not intend to defame the Holy Prophet." The second guard who was standing and keeping an eagle's watch on his surroundings said, "Contrary to your feeling, the Muslims believe that you have insulted Islam and the holy prophet in your book. They further believe that the concocted story of your book is your mad imagination. They may feel that you and your accomplices left pernicious scars on every Muslim by publishing this fake and bogus book, and these scars are difficult to be erased."

The first guard seemed tired. He stretched his legs on the table in front and said, "You have to discern this fact that the opposition to your published book some years back was hailed, upheld, and unanimously endorsed by Muslims throughout the world.

The Muslims believe that the enemies of Islam rejoiced and reveled from the publication of this book. They consider you responsible because you not only insulted Islam but also worked for hand in glove with the enemies of Islam.”

After a period of silence, the guard taking rest responded, "You were enticed to carry out this ugly mission. If you had controlled your 'ego' and had let your 'superego' prevail upon it, you would never have undertaken the task to write down this blasphemous novel."

"Why don't you use your influence to convince your masters to get this decree rescinded?" said the guard who was looking at the paintings in the room. "I have been plaintively appealing to all, especially my friends in the West, to save me from this secluded life, fear, and impending death. However, it seems that all are helpless." The writer said while crying.

The guard who was leaning in the chair said, "You are 
banking on the support of the West to get the decision rescinded. But you fail to understand this reality that the decree is non-negotiable, and there is no room for rapprochement."

"The writer should realize this fact that the Western world has a long history of ditching its favorite clients once they have outlived their usefulness. The writer's masters believe in the dictum that as long as the cat catches mice, its color is of no importance." The writer's wife, who entered the room to serve coffee, said.

The guard leaning in the chair endorsing the views of the writer's wife and said, "The writer and his publishers are forced by concatenation of circumstances to live together and plead their innocence although the fear of the unknown would drive them to the point of exchanging blows and total annihilation."

"Have you derived any dividends from the publication of this book?", asked the guard who stood alert.

Before the writer could answer this question, his wife replied abruptly, "No, by writing this book, the writer has not scored any scholastic or literary points as being interpreted in the West. But he has served the interests of his masters and earned himself and us lifelong resentment, agony, and mental torture. It is hard to attenuate the obstinacy of the writer nor to reduce the actual dimensions of his perversity. He is living in a fond hope that the Western world would back him and use all their influence to get the religious decree rescinded."

The guard leaning in the chair and sipping his coffee said, "I have sensed this reality that apart from being burdened by the heavy cost to keep the writer safe and protected, the Western friends have to make a humiliating volte-face for the cunning part they are playing. The writer should be shrewd enough to anticipate this fact that one day forced with waning support from his masters, he would be left alone to meet the formidable challenge of life and death."

The guard continued, "Punishment is from heavens because you have insulted Mohammad, whom Allah has named as his Habib-closest friend. You have invited heaven's intense wrath by insulting Mohammad, and thus you would linger psychologically in the grip of fear and fits."

The writer said while he was sitting in a pensive mood and looked worried, "By publishing this book, although I could siphon off huge amounts of money into my accounts, yet I harbor this tangible fear day and night that my days are numbered. I am whisked away to safer abodes and hideouts by paid guards and am escorted heavily like a criminal taken to gallows in olden days. My sojourn in the U.K. and other countries to plead my case of innocence is marred by pitfalls, shattered hopes, and unfulfilled expec- tations. The hollow promises offered by host countries do not calm and tame my dejected and disgruntled soul ..."

His wife interrupted and said, "Although the writer is an accomplished orator capable of whipping up his audiences into a state of ecstasy, yet he has signally failed to placate the tortured feeling of the incensed and infuriated Muslims. He has been duped, and all his efforts at reconciliation had been futile."

The writer raised his eyebrows, looked through the window, and saw everything covered in a cloak of darkness. The pin-drop silence outside and the thick veil of darkness disturbed him. He again turned his face towards those sitting in the room, and a melancholy voice said, "My only option is to summon up my courage and wits and face the judgment by the Muslims, which is irrevocable. My fears of impending death and my unpardonable sin of writing this book had a devastating impact on my personality. I feel that I am no less than a psychic wreck, and this growing and discernible unease and change of personality of mine is being noticed by both my friends and foes."

In the corridor, the sounds of the boots of the guard on duty could be heard. The guard slipped inside to have his coffee. As he started sipping his coffee, he said, "Over the past two years during which I have been keeping a watch on your house, I have noticed that as the second tick by, your fears and horrors increase (pointing towards the writer). You might have slipped under the noses of enemies, but this is because of the thick veil of secrecy and the watchful gaze and close surveillance of the hired personnel. It is my conviction that if the cloak of secrecy about your whereabouts is lifted and the guards are set free, you stand no chance to emerge from people unscathed."

The writer's wife poured more coffee for the three of them. She looked dejected and bone-tired and said in a wailing voice, "Both him and myself are reeling under the painful and horrifying experience of death. Perhaps you would agree with me that anyone who has the tenacity to apprehend the tormenting foreseeable future would undoubtedly have sleepless nights and horrifying nightmares."

The writer nodded in affirmative. It seems he fully agreed with his wife. He cleaned his spectacles with a napkin, leaned a bit in his chair, stretched his legs, and said, "Time and again, I change my dwelling and seek sanctuary from different friends and different countries. It can be safely imagined that I get hallucinations and hear harrowing voices and noises that do not exist. The furor that my publication caused is still alive, and it would reverberate in my abode one day. My publication boomeranged, and I can predict that one day, I would be hurled to the ground and trampled to death."

The guard leaning in the chair had to change shift with 
the guard on duty. He got up from his chair, yawned a bit, straightened his uniform, and before resuming his duties to keep a watch addressed all those who were in the room and said, "Self-discipline and a sense of responsibility govern one's daily life. Anyone deprived of these sterling qualities faces hardships in life. I believe that you (pointing towards the writer) are doomed to death because you didn't exercise self-discipline in your writings. So long as you live, you would be like a vagabond in your hideouts huddled by policemen and security guards but the fear of death would hang on your head like the Damocles sword and the same invisible sword would always be there to harass you as a reward for your irresponsible publication."

Tears rolled down the cheeks of the writer's wife. Tired and depressed of the life she was leading with her husband, she said in an inaudible voice, "The intractable fear harassing him day and night is not only a supererogatory appendage to his body but a cardinal part of our life. The invisible hands and the impending death constantly harass him and disturb the calm and serene life that he once enjoyed before he embarked on his madly and devilish adventure to write his book."

The writer looked at the wall clock. It was 5:30 AM. The light of dawn was slowly creeping into the rooms. Another painful and disturbing night was over for the writer and his family.

\section{Footnote}

Conflict of Interests: There is no conflict of interest. 